Teologia i Moralność, Volumen 13(2018), numer 1(23)

doi: 10.14746/tim.2018.23.1.9

KRZYSZTOF GRYZ

Uniwersytet Papieski Jana Pawła II w Krakowie

Wydział Teologiczny

\title{
Prawo stopniowości \\ w posynodalnych adhortacjach o rodzinie Familiaris consortio i Amoris laetitia
}

Mając na uwadze złożoną dynamikę życia moralnego, w którym podejmowane decyzje naznaczone są niejednokrotnie napięciem między obiektywnym prawem Bożym a zmieniającymi się sytuacjami i okolicznościami, w jakich znajduje się człowiek, refleksja duszpasterska Kościoła wypracowała kategorię prawa stopniowości, która znalazła zastosowanie w odniesieniu do małżeństwa i życia rodzinnego w adhortacji Jana Pawła II Familiaris consortio, a później w adhortacji Franciszka Amoris laetitia. Celem niniejszego artykułu jest analiza zarówno samej kategorii prawa stopniowości, jego interpretacji teologicznych, jak też sposobu stosowania go w duszpasterstwie, które proponują wspomniane dokumenty papieskie.

\section{Geneza prawa stopniowości}

Podsumowując dyskusję nad Dokumentem podstawowym synodu na temat rodziny z 1980 roku, kard. J. Ratzinger zwrócił uwagę na fakt, że w trakcie obrad wyłoniły się dwie tendencje w podejściu do kwestii pastoralnych odnoszących się do rodziny. Jedna wskazywała na potrzebę rezygnacji z takiego języka, który sugerowałby, że doktryna została ostatecznie już sformułowana, przeciwnie doktrynę należy rozważać nie tylko z teoretycznego punktu widzenia, ale również w perspektywie pielgrzymującego Ludu Bożego, który znajdując się w drodze, napotyka wciąż nowe wyzwania i problemy. Druga tendencja reprezentowała przeciwny pogląd, twierdząc, że podstawowym zadaniem duszpasterskim jest prezentowanie niezmiennej nauki Kościoła, bo to 
od niej zależy zbawienie człowieka, a nie uleganie presji opinii czy uwarunkowaniom społecznym. W ocenie Ratzingera stanowisko wielu ojców synodu sugerowało możliwość pogodzenia obu tych tendencji i wypracowanie takiej metody pedagogicznej, „która pomogłaby ludziom dotrzeć do Ewangelii, budować mosty skracające dystans między powołaniem chrześcijańskim a konkretnym życiem" (Ratzinger 1981, s. 16-17).

Owocem takiej refleksji ojców synodu było pojawienie się tematu stopniowalności jako nowej idei przewijającej się zarówno w pracach synodu, jak i w późniejszej adhortacji. W części pierwszej dokumentu posynodalnego Elenchus propositionum, pt. Wola Boża zawarta w wędrówce Ludu Bożego, punkt trzeci pt. Gradualitas mówi o stopniowości procesu nawrócenia umysłów i serc, co z kolei ma prowadzić do przemiany struktur. Proces ten nie jest jednorazowy, lecz zakłada pewne etapy i stopnie. Poszczególni wierni, narody i cywilizacje winni być cierpliwie prowadzeni do coraz głębszego zrozumienia tajemnicy Chrystusa i pełniejszego jej zastosowania $\mathrm{w}$ życiu i obyczajach (por. Elenchus propositionum, 7).

Ze względu na niebezpieczeństwo błędnej interpretacji tej refleksji synodalnej Jan Paweł II w swym przemówieniu na zakończenie synodu ustosunkował się do niej, odrzucając wszelki rozdział czy dychotomię

pomiędzy pedagogiką, która proponuje pewną stopniowość w pełnieniu woli Boga, a proponowaną przez Kościół doktryną, razem ze wszystkimi jej konsekwencjami, a wśród nich z obowiązkiem życia według tej doktryny. W tej sprawie nie ma mowy o traktowaniu prawa jako - jak to się mówi - „ideału” do osiągnięcia kiedyś w przyszłości, ale naprawdę jako nakazu Chrystusa Pana do wytrwałego przekraczania trudności (Jan Paweł II 1986, s. 519-520).

Według Jana Pawła II prawo stopniowości jest nie do przyjęcia w odniesieniu do przykazań Bożych. Wszystkie przykazania, w całej swej rozciągłości, obowiązują każdego, w każdej sytuacji, od samego początku życia z wiary. Takie też sformułowanie pojawiło się w późniejszej adhortacji posynodalnej Familiaris consortio.

\section{Prawo stopniowości w Familiaris consortio}

Temat stopniowości pojawia się $\mathrm{w}$ dwu miejscach adhortacji. W pierwszym z nich odnosi się do ogólnie pojętego rozwoju życia duchowego człowieka, które rozpoczyna się nawróceniem, a potem stopniowym dochodzeniem do coraz pełniejszego poznania tajemnicy Chrystusa. Punktem wyjścia w mówieniu o stopniowości jest według Jana Pawła II nawrócenie umysłu 
i serca, wyrzeczenie się własnego egoizmu i naśladowanie Chrystusa Ukrzyżowanego. Mowa jest o nawróceniu w podwójnym wymiarze: najpierw jako wydarzeniu przełomowym w życiu człowieka, polegającym na uznaniu, że Bóg jest jedynym Panem i Zbawcą, po wtóre, na ciągłym nawracaniu się rozumianym jako kolejne etapy $\mathrm{w}$ dążeniu do pełni chrześcijańskiej doskonałości.

Potrzebne jest ciągłe, nieustanne nawracanie, które wymaga wewnętrznego oderwania się od wszelkiego zła i przylgnięcia do dobra w jego pełni, a które w praktyce dokonuje się często etapami, prowadzącymi coraz dalej (FC, nr 9).

Tak rozumiana stopniowość jest dynamizmem miłości inspirowanym i kierowanym przez łaskę Chrystusa ${ }^{1}$. Nawrócenie, a więc znalezienie się w obiektywnie prawej i godziwej relacji z Chrystusem, jest warunkiem postępu w doskonałości, a zatem jest także warunkiem wszelkiej stopniowości. Nie chodzi zatem o stopniowość, która jest uwarunkowana zewnętrzną zmiennością okoliczności, do których dostosowuje się człowiek, ale o wewnętrzną przemianę serca, którą oddaje pojęcie nawrócenia.

Zasadnicza treść tego, co nazywamy prawem stopniowości, pojawia się w numerze 34. adhortacji w kontekście omawiania zadań, jakie stoją przed rodziną chrześcijańską, a konkretnie dotyczących troski o życie. Jan Paweł II przyznaje, że wymagania moralne związane z nauką encykliki Humanae vitae są trudne i wymagają poświęcenia, jednak Kościół stawia je w duchu posłuszeństwa Chrystusowi, będąc przekonany, że odpowiadają one obrazowi i godności człowieka stworzonego na obraz Boga ${ }^{2}$. Małżonkowie są wezwani do „ustawicznego postępu wiedzeni szczerym i czynnym pragnieniem coraz lepszego poznawania wartości, które prawo Boże chroni i rozwija oraz prostą i szlachetną wolą kierowania się nimi w konkretnych decyzjach" (FC, nr 34).

W dalszej części adhortacji Jan Paweł II podaje właściwe rozumienie prawa stopniowości, którego granicą interpretacji jest niestopniowalność prawa. Odwołał się do swojego przemówienia na zakończenie obrad synodalnych, którego zasadnicza część została włączona do tekstu adhortacji. Po pierwsze, należy wyzbyć się wszelkiego rozdziału czy dychotomii między pedagogią, która „proponuje pewną stopniowość w pełnieniu woli Bożej a proponowaną przez Kościół doktryną, razem ze wszystkimi jej konsekwencjami, a wśród

1 „Rozwija się w ten sposób proces dynamiczny, przebiegający powoli przez stopniowe włączanie darów Bożych i wymagań Jego ostatecznej i najdoskonalszej Miłości w całe życie osobiste i społeczne człowieka" (FC, nr 9).

${ }^{2}$ „Kościół nie jest bynajmniej autorem tej normy [dotyczącej odpowiedzialnego przekazywania życia - KG], ani jej sędzią. Kościół, posłuszny prawdzie, którą jest Chrystus i którego obraz odbija się w naturze i godności osoby ludzkiej, tłumaczy normę moralną i przedkłada ją wszystkim ludziom dobrej woli, nie ukrywając, że wymaga ona radykalizmu i doskonałości” (FC, nr 33). 
nich z obowiązkiem życia według tej doktryny" (Jan Paweł II 1986, s. 519). Prawa Bożego nie można traktować jako pewnego ,ideału” możliwego do osiągnięcia w przyszłości, ale jako nakaz „Chrystusa Pana do wytrwałego przekraczania trudności”. Tylko w takiej perspektywie można interpretować prawo stopniowości:

W tej dziedzinie nie można uznać tak zwanego „procesu stopniowości” inaczej niż ze strony tego, który szczerze stara się o postępowanie wedle prawa Bożego i o dążenie do tego dobra, jakiego owo prawo strzeże i jakie popiera. Tego, co nazywa się lex gradualitatis, ,prawem stopniowości” lub drogą stopniową, nie można utożsamiać ze stopniowalnością prawa, jak gdyby w prawie Bożym miały istnieć różne stopnie i formy nakazu dla różnych osób i sytuacji. Wszyscy małżonkowie są powołani do świętości w małżeństwie według woli Boga, a to powołanie realizuje się w miarę, jak osoba ludzka potrafi odpowiedzieć na przykazanie Boże, ożywione spokojną ufnością w łaskę Bożą i we własną wolę (tamże, s. 520).

Oznacza to, że prawo stopniowości nie może być traktowane jako rozwiązanie dla kogoś, kto uznał, że wymagania prawa moralnego w jego konkretnej sytuacji są niemożliwe do zrealizowania, i w konsekwencji może czuć się zwolniony z jego zobowiązującego charakteru wobec swojej osoby. Jan Paweł II był świadomy tego, że od samego początku prawo stopniowości było narażone na interpretację w duchu etyki sytuacyjnej (zwłaszcza przez zwolenników tzw. „nowej teologii moralnej”3), stąd zdecydowane podkreślanie prawdy o niestopniowalności prawa, która to zasada ma określać granicę interpretacyjną dla prawa stopniowości.

\section{Kategoria stopniowości w innych dokumentach Magisterium}

Odniesienie do prawa stopniowości pojawia się jeszcze w trzech miejscach Magisterium Kościoła. Pierwszym jest tekst Papieskiej Rady ds. Rodziny w Vademecum dla spowiedników. O niektórych zagadnieniach moralnych dotyczacych życia matżeńskiego, które jest rekapitulacją orzeczeń Magisterium dotyczących dyscypliny spowiedniczej w sytuacjach małżeńskich i nie wnosi żadnych nowych elementów ani sugestii interpretacyjnych ${ }^{4}$. Drugim

${ }^{3}$ Do niemieckiego grona tego nurtu zaliczani są: J. Fuchs, B. Schüller, F. Böckle, A. Auer, K. Demmer, J. Gründel, F. Schloz, B. Häring, W. Korff, D. Mieth, P. Knauer. Nurt nowej teologii moralnej podkreśla kreatywny charakter ludzkiego sumienia, które stanowi nie tylko subiektywną normę ale wręcz normę autonomiczną. (Por. A. Szostek 1990).

${ }^{4}$ „Duszpasterskie «prawo stopniowości» - nie można go mylić ze «stopniowością prawa», które zmniejsza wymagania - zawiera się w żądaniu zdecydowanego zerwania z grzechem i stałego po- 
tekstem, który jednak nie przywołuje bezpośrednio tego pojęcia, jest przemówienie Jana Pawła II do uczestników kursu na temat odpowiedzialnego rodzicielstwa, w którym papież podkreśla, że nie można traktować wymagań moralnych Kościoła jako pewnego ideału, który trzeba dopasowywać, stopniować do konkretnych możliwości człowieka. Papież analizuje, co oznacza wyrażenie „konkretne możliwości człowieka”, i w konsekwencji stawia pytanie, o jakiego człowieka chodzi, czy o człowieka kierującego się pożądliwością, czy o człowieka odkupionego przez Chrystusa, który otrzymał w darze Ducha Świętego i jest w stanie dzięki łasce przezwyciężać pożądliwość lub - jeśli zgrzeszy - uzyskać łaskę przebaczenia ${ }^{5}$.

Z kolei w adhortacji Reconciliatio et poenitentia Jan Paweł II odwołuje się do refleksji synodu na temat sytuacji tych, „którzy pragną kontynuować religijną praktykę sakramentalną, lecz nie mogą tego czynić, gdyż pozostają w osobistym konflikcie z dobrowolnie przyjętymi obowiązkami wobec Boga i Kościoła. Są to sytuacje szczególnie delikatne i jakby bez wyjścia" (por. RP, nr 34). Papież stwierdza, że w tej delikatnej sprawie należy brać pod uwagę współistnienie i wzajemne oddziaływanie na siebie dwóch zasad, które są równie ważne. Pierwsza to zasada współczucia i miłosierdzia, według której Kościół stara się zawsze, na ile to możliwe, ukazywać drogę powrotu do Boga i pojednania z Nim. Druga zaś to zasada ,prawdy i wierności, dla której Kościół nie zgadza się nazywać dobra złem, a zła dobrem” (RP, nr 34). Konkludując, przypomina, że na ten temat wypowiedział się w adhortacji Familiaris consortio i to nauczanie pozostaje aktualne.

Jak widać, miejsc, w których prawo stopniowości jest przywoływane bądź expressis verbis, bądź pośrednio, jest stosunkowo niewiele. Może dawać do myślenia fakt, że temat prawa stopniowości nie pojawia się późniejszym nauczaniu Jana Pawła II, m.in. w tych dokumentach, które z uwagi na poruszane zagadnienia uzasadniałyby podjęcie tego tematu. Nie znajdujemy go w encyklice Veritatis splendor (6 sierpnia 1993) czy w liście do rodzin Gratissimam

dążania ku pełnemu zjednoczeniu z wolą Boga i Jego miłosnymi wymaganiami” (Papieska Rada ds. Rodziny 1997, nr 9). W przypisie 43. tekst odwołuje się bezpośrednio do Familiaris consortio, 34.

5 „Trudnością prawdziwą jest to, że w sercu mężczyzny i kobiety mieszka pożądliwość, a pożądliwość popycha wolność do tego, żeby nie zgadzała się na autentyczne wymagania miłości małżeńskiej. Byłoby bardzo wielkim błędem wyciągać z tego wniosek, że norma, jakiej uczy Kościół, jest sama w sobie tylko «ideałem», który trzeba potem przystosowywać, dopasowywać, stopniować - mówi się - do konkretnych możliwości człowieka według «wyważenia różnych dóbr, o których mowa». Ale jakie są «konkretne możliwości człowieka»? I o jakim człowieku jest mowa? O człowieku opanowanym przez pożądliwość czy o człowieku odkupionym przez Chrystusa [...] Jeżeli człowiek odkupiony jeszcze grzeszy, to nie z powodu niedoskonałości odkupieńczego aktu Chrystusowego, lecz z powodu woli człowieka wymknięcia się z łaski, która wypływa z tego aktu. Przykazanie Boże jest na pewno dostosowane do zdolności człowieka, ale do zdolności człowieka, który otrzymał w darze Ducha Świętego, człowieka, który, jeżeli popadł w grzech, może zawsze otrzymać przebaczenie i cieszyć się obecnością Ducha” (Jan Paweł II 2001, s. 267). 
sane (2 lutego 1994). Nie ma go także w dokumencie Kongregacji Nauki Wiary List do biskupów Kościoła katolickiego na temat przyjmowania Komunii św. przez wiernych rozwiedzionych żyjących $w$ nowych związach (14 września 1994) ${ }^{6}$. Fakt ten może wskazywać na to, że papież był świadomy, iż może być ono nadużywane w interpretacji, i rezygnował $\mathrm{z}$ tego pojęcia, aby nie dawać ku temu powodu.

\section{Interpretacja prawa stopniowości i stopniowalności prawa}

W literaturze teologicznomoralnej dają się wyodrębnić dwa kierunki interpretacyjne. Pierwszy za punkt wyjścia przyjmuje bezwzględną normatywność prawa moralnego i poszukuje sposobu jego konkretnej realizacji w indywidualnej sytuacji podmiotu. Drugi przeciwnie, za punkt wyjścia przyjmuje historyczną sytuację konkretnej osoby i szuka sposobów, w jaki można do niej dotrzeć z wymaganiem normy moralnej i skłonić ją do jej zachowania.

\section{a) „Normatywna” interpretacja prawa stopniowości}

Pierwszy kierunek interpretacji zakłada, że norma moralna zawsze zachowuje swoją uniwersalną wartość, choć jej wypełnienie może mieć stopniowy charakter, związany z moralnymi predyspozycjami konkretnej osoby i uwarunkowaniami zewnętrznymi, w jakich się znajduje: działający kieruje się zawsze tą samą normą w całej jej pełni, choć w danej chwili nie zrealizował jej w pełni. Niemniej jednak, niezmienna treść normy pozostaje zawsze punktem nie tylko odniesienia, ale również punktem docelowym, na którym koncentruje się intencja podejmującego działanie. Mówiąc obrazowo, grzesznik chce być świętym, mimo iż w dążeniu do tego celu kolejny raz upadł. Zawsze jednak obiektywne prawo pozostaje dla niego nadal bezpośrednim nakazem i wyzwaniem ${ }^{7}$. Tylko w takiej perspektywie możliwe jest ostatecznie mówienie o stopniowości w dążeniu do cnoty.

${ }^{6}$ „Wierny, który żyje stale na sposób małżeński (more uxorio) z osobą, która nie jest prawowitą małżonką albo prawowitym mężem, nie może przystępować do Komunii św. Jeśli zaś sądzi on, że jest to możliwe, ze względu na ciężkość materii i na to, czego wymaga dobro duchowe osoby (por. 1 Kor 11,27-29) oraz dobro wspólne Kościoła, pasterze i spowiednicy muszą pouczyć go, że taki sąd sumienia jawnie sprzeciwia się nauczaniu Kościoła (por. Kodeks prawa kanonicznego, kan. 978, par. 2). Powinni także przypominać tę naukę w nauczaniu wszystkich wiernych im powierzonych" (Kongregacja Nauki Wiary 1994, nr 6).

${ }^{7}$ Takie rozumienie uniwersalności normatywnej prawa potwierdził Jan Paweł II, odnosząc się w Familiaris consortio do prawa stopniowości, kiedy stwierdzał, że małżonkowie nie mogą „,patrzeć na prawo tylko jako na czysty ideał osiągalny w przyszłości, lecz powinni traktować je jako 
Tak rozumiane prawo stopniowości jest elementem pedagogii Boga, który cierpliwie prowadzi człowieka do doskonałości, do której każdy jest powołany. Początkiem tej drogi jest zawsze akt nawrócenia, czyli moment nie tylko uświadomienia sobie popełnianego zła, ale też szczera wola całkowitego zerwania ze złem i przylgnięcia do dobra ${ }^{8}$. Od tego momentu rozpoczyna się mozolna droga do chrześcijańskiego ideału doskonałości. Profesor Tadeusz Styczeń w komentarzu do Vademecum twierdzi, że z tego względu prawo stopniowości, zakładając doświadczenie nawrócenia, nie może stosować się do sytuacji człowieka, który pozostaje w grzechu. Odnosi się zatem do przykazań pozytywnych, zachęcających do większego wzrostu w miłości i czynienia dobra (por. T. Styczeń 1999, s. 148-150). Temu procesowi towarzyszy działanie łaski, która stopniowo przezwycięża osobistą niedoskonałość, wobec której należy być wyrozumiałym. Ta wyrozumiałość jednak, jak pisał Jan Paweł II, „nie oznacza nigdy zniekształcenia ani zafałszowania miary dobra i zła w celu dostosowania jej do okoliczności. [...] Nie sposób zgodzić się z rozumowaniem kogoś, kto z własnej słabości czyni kryterium prawdy o dobru" (VS, nr 104).

Potwierdzeniem dla takiej interpretacji prawa stopniowości jest ewangeliczny wzór głoszenia moralnych wymagań przez Chrystusa, który nie pomniejsza ich mimo niezrozumienia lub chwilowej niedyspozycji słuchaczy. Kierując się tym wzorem, teologia moralna, z uwagi na złożoność sytuacji, w jakiej znajduje się każdy człowiek ze swoją niepowtarzalną historią, wskazuje jednak, że ,prawidłowa postawa duszpasterska nie powinna polegać na szukaniu wybiegów ograniczających wymogi moralne, ale na wskazywaniu sposobów, pozwalających przezwyciężyć trudności w pełnieniu nakazów Ewangelii" (Cófreces Merino, García de Haro 2004, s. 361).

\section{b) „Egzystencjalna” interpretacja prawa stopniowości}

Zwolennicy tej interpretacji wychodzą z założenia, że prawo stopniowości, jako zasada regulująca postęp życia moralnego, jest owocem przemian w spojrzeniu na człowieka jako podmiotu moralnego znajdującego się w dynamicznej interakcji pośród wielu uwarunkowań charakteryzujących historyczność bytu ludzkiego. Wobec takiej sytuacji tradycyjna antropologia "statyczna" oparta na naturze człowieka (której istnienie w gruncie rzeczy się kwestionu-

nakaz Chrystusa do wytrwałego przezwyciężania trudności” (FC, nr 34; por. You, 1991; Świerczek 2013, s. 255-256).

${ }^{8}$ „Così come tra la vita e la morte non ci sono gradi diversi, allo stesso modo questi non esistono nella conversione cristiana come dono reale e vero a Gesù, tra la situacione di peccato e la vita in Cristo" (Kampowski, Granados, Pèrez-Soba 2016, s. 43). 
je) i wynikające z niej niezmienne normy nie odpowiadają dynamicznej wizji człowieka historycznego znajdującego się w stanie permanentnej autokreacji.

Świat ludzkiego podmiotu, jego kultura, jego wrażliwość, jego idee, jego doświadczenie nie są czymś drugorzędnym, lecz mają decydujące znaczenie dla określenia życiowego praxis i z tego powodu powinny być uświadomione, zinterpretowane, krytycznie rozpoznane jako nieunikniona droga człowieka w odkrywaniu swojej własnej powinności życiowej (Irrazábal 2004, s. 189)9 .

Odkrycie człowieka jako podmiotu historycznego zmusza do zmiany perspektywy teologii moralnej, a wręcz do całego jej przemodelowania. Twierdzi się, że posttrydencka teologia moralna była pomyślana z perspektywy prawa i ufundowana na kategorii natury ludzkiej postrzeganej jako uniwersalny i abstrakcyjny model. Dopiero na drugim miejscu sytuowała się perspektywa zastosowania prawa do konkretnych przypadków i osób.

W przeciwieństwie do tego odkrycie historycznego wymiaru podmiotu ludzkiego każe zmienić perspektywę i uczynić podmiot wraz z jego doświadczeniem historycznym elementem, jeśli nie pierwszym i podstawowym w dokonywaniu refleksji moralnej, to równie istotnym. Ta perspektywa sprawia, że waloryzowanie moralne, jak i cała moralność, winna mieć wymiar dynamiczny, a nie statyczny, właściwy dla moralności prawa. Normy zakorzenione w pewnej idei człowieka (która postrzegana jest zawsze jako wizja statyczna) stanowią perspektywę wtórną i odgrywają rolę pedagogiczną na drodze do pogłębiania doświadczenia moralnego podmiotu. To, co jest zasadnicze, to podmiot historyczny z jego osobistymi uwarunkowaniami. Jest to postulowana współcześnie tzw. „,moralność w pierwszej osobie”, a nie jak dotąd „moralność w trzeciej osobie", w której podstawową rolę odgrywało obiektywne prawo $^{10}$. W tej perspektywie zło moralne danego czynu można określić jedynie w perspektywie aktualnych zdolności moralnych podmiotu. W odniesieniu do prawa stopniowości oznacza to, że w konkretnej sytuacji nawet zło moralne może być elementem dynamiki wzrostu, ponieważ nie obciąża winą podmiotu, niezdolnego do jego rozpoznania i realizowania. Takie ujęcie prezentuje prof. Gustavo Irrazábal (por. Irrazábal 2004, s. 167-190). Według niego prawo

${ }^{9}$ Można dostrzec w takim ujęciu wpływ postulatów tzw. etyki sytuacyjnej, której naturę trafnie uchwycił wiele lat temu ks. Władysław Wicher: „Moralność sytuacyjna wznawia stare i ciągle nowe zagadnienie: zasad ogólnych i ich stosowania w życiu moralnym. Opiera się na filozofii, która neguje w poszczególnym człowieku i w sytuacjach partykularnych ogólną strukturę istoty, czyli nie uznaje, że istota jest w poszczególnym bycie w absolutnie jedyny sposób. Jak się zdaje, kryje się w tym sofizmat: z faktu, że generalne prawo nie jest zdolne objąć całkowicie konkretnej sytuacji, wnioskuje się błędnie, że sytuacja nie może w żaden sposób zależeć od tego prawa” (Wicher 1969, s. 346).

${ }^{10}$ Takie ujęcie krytykuje L. Melina (1996, s. 126). 
stopniowości polega na tym, że podmiot działa odpowiednio do swych moralnych możliwości zrozumienia i realizowania wartości (w domyśle niezależnie od obiektywnej wartości podejmowanych wyborów i działań); wówczas działa dobrze, wypełnia prawo i wzrasta w cnocie (tamże, s. 184).

$\mathrm{Z}$ takiego założenia wynikają dwie konsekwencje. Po pierwsze, obiektywne prawo moralne musi zostać skonkretyzowane $\mathrm{w}$ indywidualnym sumieniu i dopiero wówczas może stać się imperatywem do konkretnego działania, w rzeczywistości tworząc „roboczą wersję” modelowego prawa. Sumieniu przypisuje się pełną autonomię, nawet jeśli będzie „zmuszone” zmodyfikować normę, przed czym przestrzegała i co odrzucała encyklika Veritatis splendor ${ }^{11}$. Poza tym, twierdzi się, że należy rozróżnić między biernym posłuszeństwem normie (co byłoby działaniem nieodpowiadającym osobie ludzkiej), a postawą twórczego protagonizmu w realizowaniu własnej historii i doskonałości moralnej. Jeśli prawo stopniowości rozumie się jako realizowanie jasno określonego programu moralnego zawartego w prawie, wówczas osoba pozbawiona jest osobistej odpowiedzialności za znalezienie i realizowanie swojej własnej drogi życia moralnego (Irrazábal 2004, s. 188) ${ }^{12}$.

Wskazuje się także na istotne rozróżnienie, jakie istnieje między normą/ /prawem a wartością, według którego prawo nie jest adekwatnym wyrazem wartości, a wartość przewyższa swoją treścią prawo. Z tej nierównoważności wyciąga się wniosek, że dana wartość może być realizowana nie zawsze w zgodności z prawem. Tym, co jest rzeczywistym i realnym dobrem dla konkretnej osoby, jest wartość, czyli „dobro spersonalizowane”, osobiście odczytane i przyswojone, nawet jeśli nie odpowiada w pełni dobru obiektywnemu. Tę wartość, a więc to, co jest w danym momencie osobistej historii życia prawdziwym „dobrem dla mnie”, odczytuje sumienie.

11, ,...] niektórzy proponują przyjęcie swego rodzaju podwójnego statusu prawdy moralnej. Obok płaszczyzny doktrynalnej i abstrakcyjnej należałoby uznać odrębność pewnego ujęcia egzystencjalnego, bardziej konkretnego. Ujęcie to, uwzględniające okoliczności i sytuację, mogłoby dostarczać uzasadnień dla wyjątków od reguły ogólnej i tym samym pozwalać w praktyce na dokonywanie z czystym sumieniem czynów, które prawo moralne uznaje za wewnętrznie złe. W ten sposób wprowadza się w niektórych przypadkach rozdział lub nawet opozycję między doktryną wyrażoną przez nakaz o znaczeniu ogólnym a normą indywidualnego sumienia, które w praktyce miałoby stanowić ostateczną instancję orzekającą o dobru i złu. Na tej podstawie próbuje się uzasadnić tak zwane rozwiązania «pastoralne», sprzeczne z nauczaniem Magisterium i usprawiedliwić «twórczą» hermeneutykę, według której poszczególna norma negatywna bynajmniej nie we wszystkich przypadkach jest wiążąca dla sumienia" (VS, nr 56).

12 Takie stanowisko odrzuca encyklika Veritatis splendor: „Pragnąc uwypuklić «kreatywny» charakter sumienia, niektórzy autorzy określają jego akty już nie mianem «sądów», ale «decyzji»: tylko poprzez «autonomiczne» podejmowanie tych decyzji człowiek może według nich osiągnąć moralną dojrzałość. Nie brak także zwolenników poglądu, iż przeszkodę dla tego procesu dojrzewania stanowi nazbyt kategoryczne stanowisko, jakie w wielu kwestiach moralnych zajmuje Magisterium Kościoła, którego wypowiedzi jakoby wywołują na wiernych niepotrzebne konflikty sumienia" (VS, nr 55). 
Wartość domaga się odkrycia, bycia przeżywanym i chcianym, jako coś więcej niż tylko powinność, którą „należy spełnić”, lub coś co „powinno się uczynić” ze względu na mój moralny wzrost, tego co „dobre dla mnie”. Przeciwnie, norma prawa nie jest czynnikiem humanizującym, może nawet poniżać człowieka, przemieniając się nawet w najgorszą „dla mnie” alternatywę (Irrazábal 2004, s. 186).

Prawo stopniowości powinno charakteryzować się także ogólnymi zasadami dotyczącymi prawa moralnego, w tym także tego, że prawo może zobowiązywać tylko tych, którzy są w stanie je przestrzegać. Człowiek niedoskonały nie jest w stanie go przestrzegać, a więc nie może go w pełni realizować. Przytacza się św. Tomasza i jego opinię na temat obowiązywalności prawa ludzkiego, które nie zabrania wszystkich występków, od których powinni stronić ludzie cnotliwi, lecz tylko tych cięższych, „których może się powstrzymać przeważająca część masy ludzkiej. Zwłaszcza tych, które są ze szkodą dla innych" (Tomasz z Akwinu 1975-1986, II-II, q. 96, a. 3, ad 1). Uzasadnia to tym, że ,zamiarem prawa jest prowadzenie ludzi do cnoty: nie od razu, lecz stopniowo. Nie od razu przeto nakłada mnogości niedoskonałych ludzi to, co już jest udziałem urobionych w cnocie: mianowicie żeby powstrzymywali się od wszelkiego zła. W przeciwnym razie ludzie niedoskonali, nie będąc w stanie udźwignąć takowych nakazów, wpadaliby w jeszcze gorsze zło" (tamże) ${ }^{13}$. Pomija się fakt, że Tomasz mówi o prawie ludzkim, nie zaś o prawie Bożym, które jest prawem łaski kierującym życiem człowieka odkupionego. Na ten aspekt antropologii zbawienia wskazywał Jan Paweł II, mówiąc, że prawo nie może być dopasowane do konkretnych możliwości człowieka (Papieska Rada ds. Rodziny 1997, nr 9).

Zwolennicy egzystencjalnego rozumienia prawa stopniowości redukują dobro moralne do realnych możliwości konkretnego podmiotu, czyniąc w ten sposób rozróżnienie na człowieka ,idealnego" i człowieka „historycznego" (por. Irrazábal 2004, s. 189). Prawo obiektywne obowiązywałoby tylko tego pierwszego, a nie może obowiązywać człowieka żyjącego w konkretnych uwarunkowaniach. Prawo jest pewną ideą, niemożliwą do osiągnięcia w obecnym czasie przez grzesznego człowieka. Jest horyzontem, ku któremu człowiek wiecznie podąża.

W historycznych uwarunkowaniach drogi człowiek wciąż napotyka na okoliczności utrudniające pełną realizację normy, a w konsekwencji redukujące odpowiedzialność moralną podmiotu. Wyrazem tego jest rozróżnienie między grzechem formalnym a grzechem materialnym. Prawo stopniowości odnosiłoby się do grzechu materialnego (tzn. człowiek może żyć w obiektyw-

${ }^{13}$ Wskazuje się także na słowa św. Augustyna: „Bóg nie żąda rzeczy niemożliwej, lecz nakazuje swym przykazaniem to czynić, co możesz, a modlić się o to, czego jeszcze uczynić nie możesz" (Augustyn, c. 43, 50: CSEL 60, 270). 
nie grzesznej sytuacji, lecz jeśli nie jest tego w pełni świadomy lub jej wewnętrznie nie akceptuje, to wówczas może skorzystać z miłosierdzia i łaski). Trwanie w grzechu materialnym może być zatem traktowane jako pewien etap $\mathrm{w}$ dążeniu do pełnego realizowania normy moralnej. Pomija się jednak fakt, na co zwraca uwagę encyklika Veritatis splendor, że nawet wtedy, kiedy zło nie obciąża sumienia moralną odpowiedzialnością, to jednak „nie przestaje być złem, nieporządkiem w stosunku do prawdy o dobru. Co więcej, dobro nie rozpoznane nie przyczynia się do wzrostu moralnego osoby, która je czyni, gdyż jej nie doskonali i nie pomaga jej zwrócić się ku najwyższemu dobru" (VS, nr 63). Jest to szczególnie istotne wtedy, kiedy mówimy o prawie stopniowości mającym na celu duchowy wzrost i dojrzewanie człowieka.

Takie interpretacje mogą także wpływać negatywnie na praktykę sakramentu pokuty. Czyż rachunek sumienia, który jest integralnym elementem owej praktyki, nie jest właśnie stałą weryfikacją poprawnej realizacji prawa stopniowości, która dokonuje się właśnie w odniesieniu do obiektywnych norm moralnych? Jeżeli przyjmuje się, że owe normy nie mają bezpośredniego wpływu na niepowtarzalną w swym konkrecie sytuację podmiotu, i uznaje się subiektywną interpretację prawa stopniowości, to wówczas uwarunkowania historyczne podmiotu mogą prowadzić do takiego ograniczenia odpowiedzialności moralnej, że rachunek sumienia traci sens, a w konsekwencji zaciera się wartość samego sakramentu pokuty, który po zredukowaniu do jednostkowych przypadków stopniowo zatraci miejsce w praktyce życia duchowego wiernych. Warto w tym kontekście pamiętać o przestrodze Veritatis splendor:

zanim znajdziemy łatwe usprawiedliwienie, zasłaniając się własnym sumieniem, powinniśmy rozważyć słowa Psalmu: „kto jednak dostrzega swoje błędy? Oczyść mnie od tych, które są skryte przede mną" (Ps 19,13). Istnieją winy, których nie dostrzegamy, ale które mimo to nie przestają nimi być, ponieważ to my nie chcieliśmy dotrzeć do światła (por. J 9,39-41) (VS, nr 63).

\section{c) Możliwość stopniowalności prawa?}

Istotnym elementem prawa stopniowości, warunkującym jego poprawne rozumienie i stosowanie, jest przekonanie o niezmienności wymagań samego prawa moralnego, wewnątrz którego nie istnieje stopniowalność normy. Przekonanie to jest powszechnie przyjmowane. Niemniej jednak pojawia się takie rozumienie stopniowości postępu moralnego człowieka, które dotyka bezpośrednio samego prawa. Według tej koncepcji prawa nie można stosować w sposób uniwersalny do wszystkich przypadków, ale w różnym stopniu w zależności od różnych osób i ich indywidualnego stanu moralnego. Takie podej- 
ście byłoby stworzeniem szansy dla tych osób, które z rozmaitych powodów postrzegały wymagania moralne jako niemożliwe do spełnienia ${ }^{14}$.

Przykładem takiego rozumienia „stopniowalności prawa” jest wspomniany wyżej prof. Gustavo Irrazábal ${ }^{15}$. Twierdzi on, że samo pojęcie stopniowości, rozumiane jako adaptacja, dostosowanie prawa do konkretnego stopnia moralnego rozwoju podmiotu zakłada także stopniowalność samego prawa. Nie jest to stopniowalność w samym prawie jako takim (które - jak twierdzi autor - i tak nie ma bezpośredniego przełożenia na konkretne czyny człowieka), ale w jego zastosowaniu przez podmiot. O rzeczywistym realizowaniu prawa w konkretnej sytuacji decyduje zdolność moralna podmiotu do jego zastosowania. Autor powołuje się na Tomasza z Akwinu, który mówi, że potestas sive facultas operandi ex interiori habitu seu dispositione procedit ${ }^{16}$. Biorąc pod uwagę ten fakt, Tomasz stawia sobie pytanie, czy zadaniem ludzkiego prawa jest tępienie wszystkich wad i występków. Odpowiada, że ze względu na brak owej facultas prawo ludzkie nie zabrania wszystkich występków, lecz tylko tych, które są ciężkie i które szczególnie szkodzą innym. W tym kontekście Tomasz formułuje zasadę stopniowości: Lex humana intendit homines inducere ad virtutem, non subito, sed gradatim ${ }^{17}$. Ta gradacja odnosi się także do kar za nieprzestrzeganie prawa, jakie nakłada ustawodawca świecki, który w przeciwnym razie zmuszony byłby karać nawet za najmniejsze uchybienia.

Profesor Irrazábal pyta w tym kontekście, czy jeśli ustawodawca świecki rezygnuje z karania cudzołóstwa, to czy podobnie może postąpić spowiednik na forum wewnętrznym. Odpowiadając, stwierdza, że nie może tolerować grzechu formalnego, ale może tolerować grzech rozumiany w sensie materialnym, uwzględniając ów brak dyspozycyjności moralnej (facultas operandi) do zachowania czystości. „Postępowanie takiego człowieka, nie odpowiadając materialnie porządkowi cnoty, może zarazem nie naruszać tego porządku w sensie formalnym" (Irrazábal 2010, s. 183). Autor idzie jednak krok dalej

14 „Prawo byłoby interpretowane niejednakowo, dzięki czemu życie chrześcijańskie stałoby się pociągające i możliwe dla wszystkich osób, które w innych warunkach zostałyby pozbawione sakramentów, a nawet mogłyby porzucić praktyki religijne, nie będąc w stanie spełnić wszystkich swoich powinności moralnych. Należałoby na przykład stosować zasadę nierozerwalności małżeństwa w stopniu «złagodzonym» do osób po rozwodzie, które zawarły ślub cywilny, aby ich nieprawidłowa sytuacja w Kościele nie przeszkodziła im w dalszym przyjmowaniu sakramentów" (Cófreces Merino, García de Haro 2004, s. 359). Polemikę z takim rozumieniem stopniowalności podjął m.in. prof. L. Melina (1996, s. 105-136; García de Haro 1988).

${ }^{15}$ Profesor Papieskiego Uniwersytetu Katolickiego Argentyny (Pontificia Universidad Católica Argentina) z siedzibą w Buenos Aires. Konsultor Komisji Episkopatu Argentyny do spraw Wiary i Kultury (2006).

${ }^{16}$ „Możność, czyli zdolność działania, pochodzi od wewnętrznego urobienia czy usposobienia” (Tomasz z Akwinu data, I-II, q, 96, a. 2).

17 „Zamiarem prawa ludzkiego jest prowadzenie ludzi do cnoty, nie od razu lecz stopniowo”Tomasz z Akwinu data, I-II, q, 96, a. 2, ad 2. 
w interpretacji Tomasza, stwierdzając, że nawet działanie, które nie odpowiada normie, nie tylko jej nie łamie w sensie formalnym, lecz nawet może realizować sens danej cnoty (ratio virtutis), stawiając pozytywny krok do przodu w kierunku doskonałości (por. tamże, s. 185). W efekcie, to prawo dopasowuje się do poziomu moralnego człowieka, a nie odwrotnie: prawo przerastając w pewnym sensie człowieka, wyzwala w nim dynamizm moralnego wzrostu (por. tamże, s. 167-187) ${ }^{18}$.

Konkludując swoje refleksje, profesor z Argentyny wnioskuje, że na podstawie Familiarsis consortio można mówić także, wbrew pozorom, o stopniowalności prawa, ale należy je rozumieć w kontekście dynamicznym, tzn. uwzględniając dynamikę moralnego postępu człowieka, który za każdym razem stopniowo aktualizuje w sobie prawo. W statycznym rozumieniu prawa zatem nie może być mowy o jego stopniowalności, ale w dynamicznym jego rozumieniu (a tylko takie w praktyce jest dostępne człowiekowi) można mówić o jego stopniowalności.

\section{Zastosowanie prawa stopniowości w Amoris laetitia}

Zanim przejdziemy do analizy zagadnienia, konieczne wydają się dwie uwagi wstępne natury ogólnej. Po pierwsze, wcześniejsze rozważania pokazały, że aby wyeliminować nieprawidłowe kierunki interpretacyjne prawa stopniowości, trzeba je odczytywać w świetle nauczania encykliki Veritatis splendor, szczególnie tych jej fragmentów, które dotyczą relacji, jaka istnieje między prawem moralnym a sumieniem. Tego brakuje w Amoris laetitia, która w ogóle nie powołuje się na ten dokument Magisterium, zamiast tego cytuje dokument Międzynarodowej Komisji Teologicznej mówiący o tym, że prawo naturalne nie może być traktowane jako zbiór ustanowionych reguł, ale jako źródło inspiracji do osobistych wysiłków w podejmowaniu decyzji (AL, nr 305; Międzynarodowa Komisja Teologiczna 2010, s. 59).

Po drugie, dotychczasowe enuncjacje Magisterium Kościoła sytuują prawo stopniowości w kontekście problemów dotyczących zachowania zasad moralnych odnoszących się do przekazywania życia zawartych w Humanae vitae. Adhortacja Amoris laetita poszerza stosowanie tego prawa do małżonków znajdujących się w sytuacjach nieregularnych, a więc odnosi je do sytuacji, które nie są przejściowe, lecz mają charakter trwały.

${ }^{18}$ Autor powołuje się na takich autorów jak: Gatti 1992; Kiely 1994, s. 736-737; Thévenot 1985, s. 257-294; Demmer 1995. 


\section{a) Obraz drogi}

Papieżowi Franciszkowi bliski jest obraz Kościoła w drodze, opisujący nie tylko jego misyjną naturę, ale także sposób realizacji własnego powołania w konkretnych realiach historycznych (por. EG, $\mathrm{nr}$ 20-23). To napięcie między dążeniem do pełnej realizacji i ostatecznego spełnienia a świadomością wielorakich ograniczeń (zewnętrznych i wewnętrznych) znamionuje drogę chrześcijanina i ma wpływ na jego etos ${ }^{19}$. Droga do spotkania z Bogiem i realizacji pełnego ideału Ewangelii prowadzi przez poszczególne etapy, które nie zawsze odpowiadają całkiem temu ideałowi. Stąd konieczność z jednej strony właściwego rozeznania każdej sytuacji, z drugiej zaś odpowiedzialnego, ale zarazem wielkodusznego towarzyszenia.

Obraz drogi z jednej strony opisuje historyczność człowieka, zmienność warunków, w których znajduje się on w każdej niepowtarzalnej chwili swojego życia, i różnorodnych okoliczności, które na niego oddziałują. Wszystko to sprawia, że droga każdego człowieka jest bardzo indywidualna i niepowtarzalna i składa się z całego szeregu drobnych kroków, dostosowanych do możliwości idącego ${ }^{20}$. Franciszek zwraca przy tym uwagę na to, że owa wielość zmiennych czynników może także rodzić pokusę ciągłego poszukiwania zmian, co z kolei grozi kulturą tymczasowości, zagrażającą stabilności procesu wzrastania (por. AL, nr 124).

$\mathrm{Z}$ drugiej strony obraz drogi kryje $\mathrm{w}$ sobie prawdę o podążaniu w jasno określonym kierunku i ku dokładnie wyznaczonemu celowi, który pozostaje dla człowieka niezmienny i przez ową niezmienność jest konstytutywnym elementem umożliwiającym podążanie naprzód: „w sercu każdej rodziny - pisze Franciszek - musi rozbrzmiewać kerygmat, przy każdej okazji stosownej i niestosownej, aby oświetlał drogę" (por. AL, nr 290). Tylko wtedy można mówić o rzeczywistym podążaniu życiową drogą, w przeciwnym rzazie byłoby to bezładne poruszanie się w plątaninie zmiennych współrzędnych, czyli błądzenie bez celu. Konkretnym wyrazem owego kerygmatu kierującego ży-

19 „Podmiot ewangelizacji jest czymś więcej niż instytucją ukonstytuowaną i hierarchiczną. Jest on przede wszystkim ludem zmierzającym ku Bogu. Z pewnością jest to misterium sięgające korzeniami Trójcy Świętej, ale ma ono swój konkretny wymiar historyczny w pielgrzymującym i ewangelizującym ludzie, przekraczającym wszelki, choć niezbędny wyraz instytucjonalny. Proponuję zatrzymać się nieco na tym sposobie pojmowania Kościoła, mającego swą ostateczną podstawę w wolnej i bezinteresownej inicjatywie Boga" - EG, nr 111.

${ }^{20}$ „Mały krok, pośród wielkich ludzkich ograniczeń, może bardziej podobać się Bogu niż poprawne na zewnątrz życie człowieka spędzającego dni bez stawiania czoła poważnym trudnościom" - AL, nr 305. „Normalną drogą jest proponowanie małych kroków, które mogą być zrozumiane, zaakceptowane i docenione, i pociągają za sobą proporcjonalne wyrzeczenie. Natomiast domagając się zbyt wiele, nic się nie zyska. Osoba, skoro tylko będzie mogła uwolnić się od władzy, prawdopodobnie przestanie dobrze czynić" - AL, nr 271. 
ciem rodziny jest prawo Boże, które wskazuje kierunek drogi i oświetla poszczególne jej etapy:

prawo jest również darem Boga wskazującym drogę, darem dla wszystkich bez wyjątku, który można przeżywać mocą łaski, chociaż każdy człowiek rozwija się powoli przez stopniowe włączanie darów Bożych i wymagań Jego ostatecznej i najdoskonalszej Miłości w całe życie osobiste i społeczne człowieka (por. AL, nr 295).

Przekonanie o niezmienności celu chrześcijańskiego życia, wskazywanego przez ewangeliczne prawo, jak też doświadczenie historycznych realiów, w których zanurzony jest człowiek, determinują określone metody duszpasterskie, które odwołują się do prawa stopniowości.

\section{b) Ogólne zasady stopniowości w duszpasterstwie}

Podejmując temat zastosowania prawa stopniowości w duszpasterstwie małżeństw, w numerach 293-295. pt. „Stopniowość w duszpasterstwie”, adhortacja mówi o dwu kategoriach sytuacji nieregularnych, w jakich znajdują się małżonkowie i które należałoby objąć towarzyszeniem duszpasterskim stopniowo prowadzącym do małżeństwa sakramentalnego.

Po pierwsze, są to związki tylko cywilne lub sytuacje jedynie wspólnego zamieszkania bez żadnego zobowiązania formalnego. W takiej sytuacji, biorąc pod uwagę czynniki, które wskazują na znaczną stabilność związku, wzajemną odpowiedzialność za siebie i swoje potomstwo, dojrzałość ludzką wyrażającą się w zdolności do przezwyciężania trudności, można podjąć działania duszpasterskie, które będą towarzyszeniem w drodze prowadzącym do zawarcia sakramentu małżeństwa.

Do drugiej kategorii osób należą ci, którzy zdecydowali się na wspólne zamieszkanie bez widocznej woli zalegalizowania swojego związku. Taka decyzja może mieć przyczynę nie tylko w odrzuceniu wartości małżeństwa sakramentalnego, ale także w uwarunkowaniach kulturowych (sprzeciw wobec wszelkiego rodzaju związkom instytucjonalnym) i gospodarczych (małżeństwo postrzegane jako luksus, na który ich nie stać). W odniesieniu do tych osób rozeznanie powinno określić, czy istnieją jakieś elementy, które „mogą sprzyjać ewangelizacji oraz wzrostowi ludzkiemu i duchowemu" (por. AL, nr 293), a towarzyszenie miałoby na celu przekształcenie tych sytuacji w „możliwość podążania ku pełni małżeństwa i rodziny w świetle Ewangelii” (por. AL, nr 294).

Adhortacja nie wspomina w tym punkcie wyraźnie o powtórnych związkach, które zostały zawarte po rozpadzie małżeństwa sakramentalnego. Mowa 
jest jedynie w sposób ogólny o „małżeństwach tylko cywilnych”. Podejmuje natomiast ten temat w numerze 298., zachęcając duszpasterzy do właściwego rozeznania złożoności sytuacji osób rozwiedzionych, żyjących w nowym związku.

\section{c) Rozeznanie i towarzyszenie}

Adhortacja Amoris laetitia proponuje w duszpasterstwie osób rozwiedzionych, które żyją w nowym związku, najpierw właściwe rozeznanie, które powinno dotyczyć dwóch kwestii. Po pierwsze, obiektywnej sytuacji osób znajdujących się w związkach nieregularnych, po wtóre, ich osobistej odpowiedzialności moralnej za tę sytuację. Przestrzeń rozeznania powinny wyznaczać z jednej strony wierność nauce Kościoła na temat małżeństwa i rodziny, z drugiej uwzględnienie złożoności różnych sytuacji i cierpienia ludzi z powodu stanu, w jakim się znajdują ${ }^{21}$.

1) Mówiąc o rozeznaniu sytuacji małżonków, Amoris laetitia przywołuje tylko jedno zdanie z numeru 84. Familiaris consortio: „Niech wiedzą duszpasterze, że dla miłości prawdy mają obowiązek właściwego rozeznania sytuacji” (por. AL, nr 79). Rozeznanie winno zatem dokonywać się w prawdzie odnoszącej się zarówno do sytuacji poszczególnych osób, jak też do prawdy o samym małżeństwie. To podwójne zobowiązanie wobec prawdy jest także obecne w Amoris laetitia. Według Franciszka celem duszpasterskiego rozeznania jest uświadomienie sobie swojej sytuacji przed Bogiem i pamiętanie zarazem, że to rozeznanie nie może nie uwzględniać „wymagań ewangelicznej prawdy i miłości proponowanej przez Kościół” (por. AL, nr 300).

Proces rozeznania powinien charakteryzować się pięcioma etapami: (1) uznać zróżnicowanie sytuacji, w jakich znajdują się poszczególne osoby, przy czym papież podkreśla, że sytuacje te „nie powinny być skatalogowane lub zamknięte w zbyt surowych stwierdzeniach, nie pozostawiając miejsca dla odpowiedniego rozeznania" (por. AL, nr 298); (2) adekwatnie do zróżnicowanej sytuacji rozpoznać i uznać zróżnicowaną odpowiedzialność; (3) zidentyfikować te elementy, które „mogą sprzyjać ewangelizacji oraz wzrostowi ludzkiemu i duchowemu" (por. AL, nr 293) oraz uznać częściową wartość

${ }^{21}$ „W obliczu trudnych sytuacji oraz poranionych rodzin trzeba zawsze pamiętać o zasadzie ogólnej: «Niech wiedzą duszpasterze, że dla miłości prawdy mają obowiązek właściwego rozeznania sytuacji» (Familiaris consortio, 84). Stopień odpowiedzialności nie jest równy w każdym przypadku i mogą istnieć czynniki, które ograniczają zdolność podejmowania decyzji. Dlatego też należy jasno wyrażać naukę, ale trzeba unikać osądów, które nie uwzględniają złożoności różnych sytuacji i koniecznie zwracać uwagę na sposób, w jaki ludzie żyją i cierpią z powodu stanu, w jakim się znajdują" - por. AL, nr 79. 
moralną, jaka się w nich znajduje, czyli „te znaki miłości, które w jakiś sposób odzwierciedlają odblask miłości Boga” (por. AL, nr 294); (4) przyjąć, że ponieważ jest zróżnicowana odpowiedzialność, to skutki normy także mogą być różne, „ponieważ stopień odpowiedzialności nie jest równy w każdym przypadku, to konsekwencje lub skutki danej normy niekoniecznie muszą być takie same" (por. AL, nr 300); (5) wreszcie to, co szczególnie ważne z punktu widzenia tematu naszej pracy, rozeznanie musi być zgodne z prawdą głoszoną przez Kościół, a jest to podyktowane - co wyraźnie zaznacza Franciszek niestopniowalnością prawa: „Biorąc pod uwagę fakt, że w samym prawie nie ma stopniowości (por. Familiaris consortio, 34), to rozeznanie nigdy nie może nie brać pod uwagę wymagań ewangelicznej prawdy i miłości proponowanej przez Kościół" (por. AL, nr 300).

W tekście adhortacji można wyróżnić także sześć kryteriów szczegółowych, które należy wziąć pod uwagę w trakcie rozeznania, pozwalających zarazem określić, czy mamy do czynienia z procesem stopniowego wzrostu. Należą do nich: (1) dokonanie rachunku sumienia przez chwilę refleksji i skruchy; (2) ocena swojego zachowania wobec dzieci w czasie kryzysu małżeństwa; (3) czy były próby pojednania?; (4) jak wygląda sytuacja opuszczonego małżonka?; (5) jakie konsekwencje ma nowa relacja dla pozostałych członków rodziny i wspólnoty wiernych?; (6) jaki przykład daje ona młodym ludziom, którzy przygotowują się do małżeństwa?

2) Drugi wymiar rozeznania dotyczy indywidualnej odpowiedzialności moralnej. Składa się na nią wiele czynników, w tym także te, które mogą wpływać na ograniczenie odpowiedzialności moralnej działającego podmiotu. Franciszek przypomina, że „Kościół dysponuje solidną refleksją na temat uwarunkowań i okoliczności łagodzących" (por. AL, nr 301), i wymienia takie, jak: (1) nieznajomość normy; (2) mimo znajomości normy duże trudności w zrozumieniu ,wartości zawartych w normie moralnej” (por. AL, nr 301); (3) znalezienie się w pewnych warunkach, które „nie pozwalają działać inaczej”, przez co „ograniczają zdolność podejmowania decyzji" (por. AL, nr 301). Adhortacja powołuje się także na Katechizm Kościoła katolickiego mówiący o tradycyjnych w teologii moralnej czynnikach zmniejszających odpowiedzialność moralną na skutek niewiedzy, nieuwagi, przymusu, strachu, przyzwyczajeń, nieopanowanych uczuć oraz innych czynników psychicznych lub społecznych (por. KKK, nr 1735) oraz głoszący w innym miejscu o ,niedojrzałości uczuciowej, nabytych nawykach, stanach lękowych lub innych czynnikach psychicznych czy społecznych" (KKK, nr 2352). Przypis powołuje się także na fragment adhortacji o pokucie Jana Pawła II Reconciliatio et paenitentia, w którym papież, mówiąc o naturze grzechu śmiertelnego i krytykując kategorię „opcji fundamental- 
nej”, przyznaje, że mogą istnieć „sytuacje bardzo złożone i niejasne pod względem psychologicznym, które wywierają wpływ na podmiotową poczytalność grzesznika" (RP, nr 17) ${ }^{22}$.

Uwzględniając wszystkie te elementy, Franciszek stwierdza, że odpowiedzialne rozeznanie ,powinno uznać, że ponieważ «stopień odpowiedzialności nie jest równy w każdym przypadku», to konsekwencje lub skutki danej normy niekoniecznie muszą być takie same” (AL, nr 300), a zatem „nie można już powiedzieć, że wszyscy, którzy są w sytuacji tak zwanej «nieregularnej», żyją w stanie grzechu śmiertelnego, pozbawieni łaski uświęcającej” (AL, nr 301), a „skutki danej normy mogą być odmienne”, wobec czego „ze względu na uwarunkowania i czynniki łagodzące możliwe jest, że pośród pewnej obiektywnej sytuacji grzechu osoba, która nie jest subiektywnie winna albo nie jest w pełni winna, może żyć w łasce Bożej, może kochać, a także może wzrastać w życiu łaski i miłości, otrzymując w tym celu pomoc Kościoła" (AL, nr 305).

\section{d) Między ideałem małżeństwa a milosierdziem}

Franciszek jasno stwierdza - jak sam podkreśla - dla uniknięcia wszelkich błędnych interpretacji, że Kościół nie może zrezygnować z ideału małżeńskiego, który jest planem samego Boga. Prawo moralne, także w tym względzie, jest „darem Boga wskazującym drogę, darem dla wszystkich bez wyjątku” (AL, nr 295). Z tego względu „należy dbać o integralność nauczania moralnego Kościoła” (AL, nr 311) i przyjąć je „w całej swej okazałości” (AL, nr 307). Duszpasterskie rozeznanie sytuacji wyjątkowych nie może oznaczać „ukrywania światła pełniejszego ideału ani proponowania mniej, niż to, co Jezus oferuje człowiekowi” (AL, nr 307).

Franciszek wskazuje przy tym na postawy, które sprzeciwiają się temu ideałowi lub go wypaczają. Przestrzega przed nadużyciem wolności przez złe jej rozumienie i stosowanie, które prowadzi do przekonania, ,jakby poza indywidualnymi osobami nie było żadnych prawd, wartości, zasad, które nas ukierunkowują, jak gdyby wszystko było równe i na wszystko powinno się pozwolić" (AL, nr 34), co prowadzi do relatywizmu. Konsekwencją tego jest troska o to, aby unikać zgorszenia, rodzącego się z błędnego przekonania, jakoby prawo moralne uległo zmianie. Nagannymi postawami są także letniość, relatywizm i - co zaskakujące - ,przesadny szacunek” wobec ideału małżeń-

22 Jan Paweł II przestrzega jednak przed tym przechodzeniem od rozważań natury psychologicznej do budowania kategorii teologicznej, jaką jest właśnie „opcja fundamentalna”, a zwłaszcza takie jej rozumienie które ,przedmiotowo zmienia lub poddaje w wątpliwość tradycyjne pojęcie grzechu śmiertelnego". 
skiego $^{23}$. Adhortacja nie wprowadza także żadnych nowych norm typu kanonicznego (por. AL, nr 300).

Równocześnie $\mathrm{z}$ tak wyraźnym podkreśleniem ważności normy Franciszek nalega, by Kościół uczył się od Chrystusa sposobu, w jaki proponował On ów wymagający ideał, a mianowicie ze współczującą bliskością wobec osób słabych ${ }^{24}$. „Nie pomniejszając wartości ewangelicznego ideału - pisze papież - należy z miłosierdziem i cierpliwością towarzyszyć możliwym etapom rozwoju osób formujących się dzień po dniu" (AL, nr 308).

Franciszek zwraca uwagę, że w przeszłości ideał małżeństwa był przedstawiany zbyt abstrakcyjnie, w sposób, który mógł rodzić trudności w jego zrozumieniu i przyjęciu przez wiernych ${ }^{25}$. Nauczanie było skoncentrowane na kwestiach doktrynalnych, bioetycznych i moralnych, przez co małżeństwo mogło być postrzegane jako ciężar niemożliwy do udźwignięcia, zamiast jawić się jako „dynamiczny proces rozwoju i realizacji”, w którym istotny jest wymiar charyzmatyczny: życie łaską i właściwe miejsce dla indywidualnego sumienia, które pośród ograniczeń najlepiej potrafi rozeznać sytuację i odpowiedzieć na wezwanie Ewangelii ${ }^{26}$. Z jednej strony może istnieć postawa doktrynalnego zamknięcia w sztywnych schematach, co Franciszek odrzuca, z drugiej zaś jawi się konieczność elastycznego podejścia do konkretnych problemów, w jakich znajdują się małżonkowie na określonym etapie ich życiowej drogi. Z tego punktu widzenia tekst akapitu 325. jest - jeśli nie kluczowy, to reprezentatywny - dla rozumienia prawa stopniowości w Amoris laetitia:

23 „Aby uniknąć wszelkich błędnych interpretacji, należy pamiętać, że Kościół w żadnym przypadku nie może wyrzec się proponowania pełnego ideału małżeństwa, planu Bożego w całej swej okazałości. [...] Letniość, wszelkie formy relatywizmu lub przesadny szacunek, z jakim się go proponuje, byłby brakiem wierności Ewangelii, a także brakiem miłości Kościoła wobec samych młodych. Zrozumienie sytuacji wyjątkowych nigdy nie oznacza ukrywania światła pełniejszego ideału ani proponowania mniej, niż to, co Jezus oferuje człowiekowi” - AL, nr 307.

${ }^{24}$ „Wielu nie dostrzega, że orędzie Kościoła o małżeństwie i rodzinie jest wyraźnym, jasnym odzwierciedleniem nauczania i postawy Pana Jezusa, który proponując wymagający ideał jednocześnie nigdy nie stracił współczującej bliskości wobec osób słabych, jak Samarytanka czy kobieta cudzołożna" - AL, nr 39.

${ }^{25}$ „Innymi razy przedstawialiśmy ideał teologiczny małżeństwa zbyt abstrakcyjny, skonstruowany niemal sztucznie, daleki od konkretnej sytuacji i rzeczywistych możliwości rodzin takimi, jakimi są. Ta nadmierna idealizacja, zwłaszcza gdy nie obudziliśmy ufności w działanie łaski, nie pozwoliła na to, aby małżeństwo było bardziej pożądane i atrakcyjne, ale wręcz przeciwnie" - AL, nr 36.

${ }^{26}$ „Przez długi czas byliśmy przekonani, że jedynie kładąc nacisk na kwestie doktrynalne, bioetyczne i moralne, nie pobudzając do otwartości na łaskę, dostatecznie wsparliśmy rodziny, umacniając więź małżonków i wypełniliśmy sensem ich wspólne życie. Trudno nam zaprezentować małżeństwo bardziej jako dynamiczny proces rozwoju i realizacji, niż jako ciężar, który trzeba znosić przez całe życie. Z trudem dajemy też miejsce dla sumienia wiernych, którzy pośród swoich ograniczeń często odpowiadają najlepiej jak potrafią na Ewangelię i mogą rozwijać swoje własne rozeznanie w sytuacji, gdy wszystkie systemy upadają. Jesteśmy powołani do kształtowania sumień, nie zaś domagania się, by je zastępować" - AL, nr 37 . 
Kontemplowanie pełni, której jeszcze nie osiągnęliśmy pozwala nam także na zrelatywizowanie historycznej drogi, którą idziemy jako rodziny, abyśmy przestali wymagać od relacji międzyludzkich takiej doskonałości, czystości intencji i konsekwencji, które można znaleźć jedynie w ostatecznym królestwie. Ponadto kontemplowanie pełni uniemożliwia nam też surowe osądzanie tych, którzy żyją w warunkach wielkiej słabości. Wszyscy jesteśmy powołani, aby nieustannie dążyć ku temu, co nas przekracza, w tym pokonywania naszych ograniczeń, a każda rodzina powinna żyć tą nieustanną zachętą (AL, nr 325).

Jako że małżeństwo jest dynamicznym procesem, którego nie da się w pełni zaszufladkować w sztywne schematy i klasyfikacje, co potwierdza duszpasterskie rozeznanie wskazujące na złożoność sytuacji, stąd trudno wymagać od każdego realizowania w jednakowy sposób wzniosłego ideału małżeństwa, „odtworzenia doskonałego związku między Chrystusem a Kościołem” - jak czytamy w adhortacji, bo byłoby to nakładanie ogromnego ciężaru trudnego do udźwignięcia ${ }^{27}$.

Teza, że ideał małżeństwa jest czymś niemal nieosiągalnym, może rodzić wątpliwości na temat sposobu realizacji całego procesu doskonałości chrześcijańskiej. Ojciec prof. Jarosław Kupczak w rozmowie z Tomaszem Jaklewiczem stwierdza: „uważam, że ten wyraźnie zaznaczony rozdział między ideałem a tym, co wierni mogą przyjąć, to teologicznie jedno z najsłabszych miejsc adhortacji. [...] To przecież ideał, a nie przeciętność, nas pociąga i wzywa do nawrócenia. [...] Odkąd to Kościołowi zależy na przeciętności”"28. Podobnie wypowiadał się ks. prof. Paweł Bortkiewicz na sympozjum w Krakowie nt. Kościól wobec matżeńskich sytuacji nieregularnych (17 listopada 2016): „W nauczaniu Jana Pawła II prawo stopniowości oznacza stopniowe wchodzenie ku szczytom, wspinanie się ku górze, jaką jest zjednoczenie z Bogiem, a w nauczaniu papieża Franciszka prawo stopniowości zostaje użyte w kontekście schodzenia w dół i przyzwolenia na sytuacje słabości, a więc stanowi pewien bardzo niebezpieczny temat interpretacyjny"29.

Priorytetem w spojrzeniu na rodzinę jest w Amoris laetitia miłosierdzie, to $\mathrm{z}$ tej perspektywy papież zachęca do duszpasterskiego rozeznania sytuacji, w jakich znajdują się małżonkowie. Miłosierdzie jest największym przymiotem Boga, w którym ujawnia się pełnia Jego sprawiedliwości i miłości. Ta

27, „...] nie należy mylić różnych poziomów: nie należy zrzucać na dwie osoby mające swoje ograniczenia ogromnego ciężaru konieczności odtworzenia doskonałego związku między Chrystusem a Kościołem, ponieważ małżeństwo oznacza proces dynamiczny, przebiegający powoli przez stopniowe włączanie darów Bożych" - AL, nr 122.

${ }^{28}$ Przeciętność to nie ideat. O debacie wokót adhortacji „Amoris laetitia” $i$ wierności nauczaniu Jana Pawta II o rodzinie mówi Jan Pawet II, „Gość Niedzielny” 5 marca 2017, 9 (2017), s. 28.

${ }^{29} \mathrm{https}$ ://ekai.pl/krakow-sympozjum-kosciol-wobec-malzenskich-sytuacji-nieregularnych/ [dostęp: 20.03.2017]. 
prawda powinna mieć wpływ na postawę miłosierdzia, która jest właściwą drogą Kościoła i nie pozwala odrzucać nikogo, a zwłaszcza nie pozwala zamykać drogi do Boga w sposób ostateczny. „Nikt nie może być potępiony na zawsze, bo to nie jest logika Ewangelii! Nie mam na myśli tylko rozwiedzionych, żyjących w nowych związkach, ale wszystkich niezależnie od sytuacji, w jakiej się znajdują" (AL, nr 297) ${ }^{30}$.

W tym kontekście znamienny jest fakt, że ewangelicznym obrazem, często przywoływanym w adhortacji, jest spotkanie Jezusa z cudzołożną kobietą (por. J 8,1-11), a także z Samarytanką przy studni Jakubowej, której status małżeński również był nieuregulowany (por. J 4,1-30), które to obrazy pojawiają się w adhortacji równie często jak fundamentalne nauczanie Jezusa na temat nierozerwalności małżeńskiej (por. Mt 19,1-9: 7; Mk 10,1-12).

Temu podejściu duszpasterskiemu może przeszkadzać - zdaniem Franciszka - „rozwijanie zimnej moralności przy biurku” zamiast logiki przebaczania, towarzyszenia, czekania i włączania (AL, nr 311-312). W odniesieniu do prawa moralnego pojawia się obraz „rzucanych kamieni” (AL, nr 49) czy „,norm ze skały” (AL, nr 49). Używając tak wyrazistych metafor, papież przestrzega przed duszpasterstwem, które jest niewrażliwe na złożone sytuacje ludzkie, trudne do jednoznacznego osądu, co może powodować odczucie, że osoby czują się porzucone przez Kościół, który powinien być dla nich Matką ${ }^{31}$.

Papież przestrzega także przed postawą zachowawczą, ograniczającą się do ustalonych reguł, „zdoktrynizowania” Ewangelii, zamieniania Kościoła w „urząd celny”, a pasterzy w „kontrolerów łaski”32 czy też stawiania warunków miłosierdziu. W przeciwieństwie do takiej postawy Franciszek zachęca do podejmowania ryzyka duszpasterskiego, które jest związane z postawą miłosierdzia ${ }^{33}$, a także

30 „Drogą Kościoła, począwszy od Soboru Jerozolimskiego, jest zawsze droga Jezusa: droga miłosierdzia i integracji [...]. Drogą Kościoła jest niepotępianie nikogo na wieczność; ofiarowanie miłosierdzia Boga wszystkim ludziom, którzy szczerym sercem o to proszą" - AL, 296. Por. Franciszek, Homilia podczas Mszy św. z nowymi kardynałami (15 lutego 2015), „Acta Apostolicae Sedis” 107 (2015), s. 257; „L'Osservatore Romano”, wyd. polskie 2 (2015), s. 35.

31 „W trudnych sytuacjach, w jakich żyją osoby najbardziej potrzebujące, Kościół musi zachować szczególną uwagę, aby zrozumieć, pocieszyć, włączyć, unikając narzucania im zestawu norm, jakby były ze skały, zyskując w ten sposób efekt, że czują się osądzone i porzucone przez tę Matkę, która jest powołana, by nieść im Boże miłosierdzie” - AL, nr 49.

32 „Czasami zachowujemy się jak kontrolerzy łaski, a nie jak ci, którzy ją przekazują. Kościół jednak nie jest urzędem celnym, jest ojcowskim domem, gdzie jest miejsce dla każdego z jego trudnym życiem" - AL, nr 310.

33 „Rozumiem tych, którzy wolą duszpasterstwo bardziej rygorystyczne, nie pozostawiające miejsca na żadne zamieszanie. Szczerze jednak wierzę, że Jezus Chrystus pragnie Kościoła zwracającego uwagę na dobro, jakie Duch Święty szerzy pośród słabości: Matki, która wyrażając jednocześnie jasno obiektywną naukę nie rezygnuje z możliwego dobra, lecz podejmuje ryzyko pobrudzenia się ulicznym błotem" - AL, nr 308. 
proponuje - jak to określa - cierpliwy realizm ${ }^{34}$. O cnocie cierpliwości mówi wielokrotnie, wskazując na takie jej przejawy, jak: „,cierpliwe słuchanie”, „,cierpliwą nadzieję”, ,cierpliwą ufność”, „cierpliwe nauczanie” i „cierpliwą modlitwę”. Poświęca jej nawet oddzielny akapit (por. AL, nr 91), rozwijając w nim teologię cierpliwości, odwołując się do wierności Boga w swoim przymierzu i postępowania samego Jezusa, który w spotkaniu z ludźmi kierował się „miłością i czułością, towarzysząc ich krokom z prawdą, cierpliwością i miłosierdziem, głosząc wymagania Królestwa Bożego" (por. AL, nr 60). To właśnie cierpliwość jest według papieża wypełnieniem przez Boga miłosierdzia wobec grzeszników ${ }^{35}$. Duszpasterskie towarzyszenie powinno również cechować się tym samym: ,nie pomniejszając wartości ewangelicznego ideału, należy z miłosierdziem i cierpliwością towarzyszyć możliwym etapom rozwoju osób formujących się dzień po dniu, czyniąc miejsce dla miłosierdzia Pana, zachęcającego nas do czynienia możliwego dobra" (AL, nr 308).

\section{Prawo stopniowości czy prawo przeskoku?}

Celem prawa stopniowości jest doprowadzenie człowieka do takiej dojrzałości duchowej i moralnej, aby mógł on zmienić swoją obiektywną sytuację zła i w konsekwencji przyjąć dar sakramentalnego przebaczenia oraz przystąpić do Komunii Świętej. W jaki sposób możliwe jest jednak przejście z sytuacji bliskiej i dobrowolnej okazji do grzechu ciężkiego, jakim jest cudzołóstwo, do sytuacji, w której nie zmieniając zasadniczych elementów owej sytuacji, można przyjmować Komunię Świętą? W adhortacji czytamy:

Ze względu na uwarunkowania i czynniki łagodzące możliwe jest, że pośród pewnej obiektywnej sytuacji grzechu osoba, która nie jest subiektywnie winna albo nie jest w pełni winna, może żyć w łasce Bożej, może kochać, a także może wzrastać w życiu łaski i miłości, otrzymując w tym celu pomoc Kościoła (AL, nr 305) ${ }^{36}$.

34 To pojęcie pojawia się w odniesieniu do procesu wychowawczego, o którym pisze w numerach 271-273. „Gdy proponujemy wartości, trzeba iść krok po kroku, czynić postępy na różne sposoby, w zależności od wieku i konkretnych możliwości osób, nie usiłując stosować sztywnych i niezmiennych metod. Cenny wkład psychologii i nauk pedagogicznych wskazuje na potrzebę procesu stopniowego w osiąganiu zmiany zachowań, ale także, iż wolność wymaga ukierunkowania i bodźców, ponieważ pozostawiona sama sobie nie może zapewnić dojrzewania. Wolność umieszczona w konkretnym kontekście, realna, jest ograniczona i uwarunkowana” - AL, nr 273.

35 „Cierpliwość Boga jest wypełnianiem miłosierdzia wobec grzeszników i ukazuje prawdziwą moc" - AL, nr 91.

${ }^{36}$ Encyklika Veritatis splendor zdaje się postrzegać tę sprawę w innej perspektywie: „Zło dokonane z powodu niepokonalnej niewiedzy lub niezawinionego błędu sumienia może nie obciążać człowieka, który się go dopuścił, ale także w tym przypadku nie przestaje być złem, nieporządkiem w stosunku do prawdy o dobru. Co więcej, dobro nie rozpoznane nie przyczynia się do wzrostu mo- 
Co oznacza konkretnie wyrażenie: „,pośród pewnej obiektywnej sytuacji grzechu"? Czy chodzi o sytuację zła, w której człowiek znajduje się wbrew swojej woli? Wówczas nie możemy mówić o winie i grzechu. Czy raczej oznacza bliską i dobrowolną okazję do grzechu, którego człowiek jest świadomy, czy też bliską (proxima), lecz niedobrowolną lub dobrowolną, ale daleką (remota) okazję? Każda z tych sytuacji wnosi inną okoliczność, która może rzeczywiście wpływać na ocenę moralną. Określenie użyte w adhortacji, przypominające swoją formą klasyczne formuły moralnego rozstrzygnięcia, jest w tym względzie zbyt ogólne. Można przypuszczać, że odnosi się ono do osób żyjących more uxorio w ponownym związku po rozpadzie małżeństwa sakramentalnego. Czy sytuacja oddalenia żony i związania się z inną kobietą, oceniona przez Chrystusa jako cudzołóstwo („Kto oddala żonę swoją, a bierze inną popełnia cudzołóstwo" - Mk 10,11), wskutek okoliczności łagodzących przestaje nosić znamiona tego grzechu? Jakie zatem okoliczności łagodzące mogły sprawić, że przestaje być ona grzechem ciężkim? Czy są nimi poważne racje, dla których osoby pozostające w związku nie mogą się rozejść (o czym mówiła już Familiaris consortio), długi okres, w którym trwało pożycie intymne, niemożność powstrzymania się od aktów seksualnych, współżycie jako integralny element więzi małżeńskiej? Czy decyduje o tym ostatecznie sumienie ${ }^{37}$

Jest prawdą, że trudna obiektywna sytuacja człowieka (wynikająca z wielu okoliczności) może sprawić, że ponownie popełni on grzech, ale - jak pisał Jan Paweł II - przewidywalność nowego upadku „nie przesądza o autentyczności postanowienia" - na co powołuje się Amoris laetitia w przypisie 364 (por. Jan Paweł II 1996, s. 589). Jednak czy uprzednia zgoda na ponowny grzech, a taką sytuację musielibyśmy przyjąć w przypadku osób trwających w powtórnym związku, jest takim właśnie przypadkiem? Wówczas to, co jest przewidywane, zamienia się w to, co akceptowane.

W zależności od tego, jak rozstrzygnie się tę kwestię, możliwe są różnorodne rozwiązania duszpasterskie, które nie są jednoznacznie sformułowane

ralnego osoby, która je czyni, gdyż jej nie doskonali i nie pomaga jej zwrócić się ku najwyższemu dobru" - VS, nr 63.

37 „Sumienie może jednak uznać nie tylko to, że dana sytuacja nie odpowiada obiektywnie ogólnym postanowieniom Ewangelii. Może także szczerze i uczciwie uznać to, co w danej chwili jest odpowiedzią wielkoduszną, jaką można dać Bogu i odkryć z jakąś pewnością moralną, że jest to dar, jakiego wymaga sam Bóg pośród konkretnej złożoności ograniczeń, chociaż nie jest to jeszcze w pełni obiektywny ideał" - AL, nr 303. Trzeba jednak pamiętać, że kompetencja indywidualnego sumienia nie jest absolutna, gdyż nie jest ono wolne od niebezpieczeństwa błędu (por. VS, nr 62). J. Ratzinger pisze: „Czy Bóg przekazuje ludziom niespójną naukę? Czy przeczy On samemu sobie? Czy nakazuje On jednym wstrzymanie się od jakiegoś czynu nawet za cenę męczeństwa, innym zaś pozwala go popełnić, lub wręcz tego wymaga? Z całą pewnością nie można utożsamiać osądu każdego indywidualnego sumienia z głosem Bożym" - Ratzinger 1985, s. 19. 
w samej adhortacji. Wśród nich może być także ta, która dotyczy dyscypliny sakramentalnej (słynny przypis 336). Papież nie wiąże bowiem wyraźnie decyzji o dopuszczeniu do Komunii Świętej z koniecznością podjęcia zobowiązania do wstrzemięźliwości od pożycia małżeńskiego, czyli od powstrzymania się od cudzołóstwa. Nigdzie nie przytacza rozstrzygnięcia Familiaris consortio z numeru 84. z warunkami, które muszą być spełnione, aby otrzymać rozgrzeszenie sakramentalne, które otworzyłoby drogę do Komunii eucharystycznej. Co więcej, Franciszek zwraca uwagę, że „wielu znając i przyjmując możliwość pozostawania w związku «jak brat i siostra», którą oferuje im Kościół, odkrywają, że jeśli brak pewnych wyrazów intymności nierzadko wierność może być wystawiona na próbę, a dobro potomstwa zagrożone" (AL, nr 298, przyp. 329) ${ }^{38}$. Dlatego abp Vincenzo Paglia, przewodniczący Papieskiej Rady ds. Rodziny w czasie sympozjum w Krakowie 27 maja 2016 roku, odpowiadając na pytanie, czy papież dopuszcza Komunię dla rozwiedzionych, stwierdził: „on mówi «nie», ale czy nie ma takich przypadków - też mówi «nie»”, co oznacza - powiedział dalej - że „myli się ten, który udziela Komunii i ten, który jej nie udziela" 39 .

${ }^{38}$ Papież Franciszek powołuje się w tym miejscu na nauczanie Soboru Watykańskiego II, Konstytucja duszpasterska o Kościele w świecie współczesnym Gaudium et spes, 51, które podkreśla wagę intymnego pożycia małżonków, a jego zerwanie może mieć negatywny wpływ na pożycie małżonków.

${ }^{39}$ Por. także: Dokument konferencji biskupów regionu Buenos Aires Kryteria podstawowe dla aplikacji rozdziału VIII Amoris laetitia (5 września 2016) stwierdza, że celem działań duszpasterskich nie jest doprowadzenie do Eucharystii, ale chodzi o towarzyszenie i rozeznanie, które może skierować do różnych form większej integracji w życie Kościoła (nr 1). Gdy to się dokona w przypadku jakiejś pary, można jej zaproponować wstrzemięźliwość seksualną, która otwiera drogę do sakramentów. Zdaniem biskupów, Amoris laetitia uznaje jednak, że wstrzemięźliwość ta może być trudna i jeśli dochodzi się do rozeznania, że „w konkretnym przypadku istnieją ograniczenia, które zmniejszają odpowiedzialność i winę (por. nr 301-302), szczególnie jeśli bierze się pod uwagę dobro dzieci z nowego związku, Amoris laetitia otwiera możliwość dopuszczenia do sakramentów pojednania i Eucharystii (por. przypisy 336 i 335). One dzięki sile łaski przyczyniają się do dalszego dojrzewania i wzrostu takich osób" (nr 6), por. http://infocatolica.com/?t=ic\&cod=27336 [dostęp: 25.03.2017]. Papież w liście do autorów stwierdził, że interpretacja ta w pełni oddaje sens tego rozdziału, co więcej pisze, że „nie ma innej interpretacji”. W podobnym duchu wypowiedział się abp Sokrates Villegas przewodniczący konferencji Episkopatu Filipin (14 kwietnia 2016).

Inne rozwiązanie proponuje abp Filadelfii przewodniczący Konferencji Episkopatu Stanów Zjednoczonych Charles Chaput Wytyczne duszpasterskie dla wdrożenia w życie Amoris laetitia (6 lipca 2016). Podtrzymując tradycyjne nauczanie Kościoła, stwierdza, że skoro adhortacja nie wprowadza żadnych nowych norm prawnych, to musi być czytana w duchu kontynuacji, czyli w jedności z całą tradycją nauczania kościelnego. W pełni akceptuje wytyczne Familiaris consortio o konieczności powstrzymania się od aktów, które przysługują wyłącznie małżonkom związanym węzłem kanonicznym. Natomiast jednak, jeśli upadną w czystości, powinni korzystać z sakramentu pokuty, bowiem „mają prawo odwoływać się do wielkiego miłosierdzia Boga w tym sakramencie”. Podobnie stwierdzili biskupi kanadyjskiej prowincji Alberta-Northwest (24 września 2016), por. https://www.catholicculture.org/culture/library/view.cfm?recnum=11306 [dostęp: 15.04.2017]. 


\section{Zakończenie}

Trzy czynniki odgrywają kluczową rolę w prawie stopniowości w rozumieniu Amoris laetitia. Po pierwsze, zróżnicowanie sytuacji życiowych małżonków i osób żyjących w związkach niesakramentalnych, mogące jednak być traktowane - po odpowiednim duszpasterskim podejściu (rozeznanie, towarzyszenie i włączanie) - jako etapy w drodze do pełni życia Bożego. Po wtóre, nieograniczone miłosierdzie Kościoła, który z wrażliwością dobrej Matki podchodzi z indywidualnym rozeznaniem i troską do każdego przypadku i chce przyjść z pomocą w trudnej sytuacji życiowej, a nigdy nie chce potępiać na zawsze. Po trzecie zaś, dowartościowanie indywidualnego sumienia, które odczytuje w każdym przypadku indywidualną winę. Spotkanie tych trzech czynników decyduje o podjęciu kolejnego kroku w procesie stopniowego wzrostu. Jaki powinien on być...? Wydaje się, że adhortacja Amoris laetitia pozostawia to pytanie otwarte, zarówno dla duszpasterzy, jak i dla małżonków.

\section{LAW OF GRADUALNESS IN THE POST-SYNODAL EXHORTATIONS ON THE FAMILY FAMILIARIS CONSORTIO AND AMORIS LAETITIA}

\section{SUMMARY}

Moral life is a dynamic process of constant recognizing of God's will and the man's response to God in the concrete conditions in which man finds himself. This process is marked by a specific tension between the objective and unchangeable law of God, and the changing situations and circumstances that give human choices unique character. Bearing in mind that dynamism, the Church's pastoral reflection developed a category of gradual law that applied to marriage and family life in the exhortation of John Paul II, Familiaris consortio and later in Francis' exhortation Amoris laetitia. The purpose of the article is to analyze both the category of the law of gradualness, its theological interpretations, and the manner in which it can be applied in the pastoral practice offered by the papal documents.

Keywords: moral law; conscience; marriage; pastoral care of the family; hierarchical Magisterium; Pope John Paul II; Pope Francis

Słowa kluczowe: prawo moralne; sumienie; małżeństwo; duszpasterstwo rodzin; Magisterium Kościoła; Jan Paweł II; Franciszek 


\section{LITERATURA}

Augustyn, De natura et gratia, c. 43, 50: CSEL 60, 270.

Cófreces Merino E., García de Haro R. (2004), Teologia moralna fundamentalna, tłum. A. Liduchowska, Kraków.

Franciszek (2016), Adhortacja apostolska Amoris laetitia (19 marca 2016), https://opoka.org.pl/ biblioteka/W/WP/franciszek_i/adhortacje/amoris_laetitia_19032016.html [dostęp: 31.05.2018].

Franciszek (2015), Adhortacja apostolska Evangelii gaudium (24 listopada 2013), http://www.nied ziela.pl/download/adhortacja_evangelii_gaudium.pdf [dostęp: 31.05.2018].

Franciszek, Homilia podczas Mszy św. z nowymi kardynałami (15 lutego 2015), „Acta Apostolicae Sedis" 107, s. 257.

García de Haro R. (1988), Gradualidad de la ley y ley de la gradualidad, w: AA.VV., La paternidad responsable, Madryt, s. 107-128.

Irrazábal G. (2004), La ley de la gradualidad como cambio de paradigma, „Moralia” nr 27, s. 167-190.

Irrazábal G. (2010), ¿Existe una gradualidad inherente a la ley moral?, „Revista Teología” nr 47, s. $167-187$.

Jan Paweł II (1981), Adhortacja apostolska Familiaris consortio (22 listopada 1981), https://opoka. org.pl/biblioteka/W/WP/jan_pawel_ii/adhortacje/familiaris.html [dostęp: 31.07.2018].

Jan Paweł II (1993), Encyklika Veritatis splendor (6 sierpnia 1993), https://opoka.org.pl/ biblioteka/W/WP/jan_pawel_ii/encykliki/veritatis_1.html [dostęp: 31.07.2018].

Jan Paweł II (1996), Lettera al Card. William W. Baum in occasione del corso sul foro interno organizzato dalla Penitenzieria Apostolica (22 marca 1996), 5: Insegnamenti, XIX, 1.

Jan Paweł II (1986), Nikt nie może realizować miłości inaczej niż w prawdzie (25 października 1980), 8, w: Jan Paweł II, Nauczanie papieskie, t. III/2, Poznań-Warszawa, s. 517-521.

Jan Paweł II (1984), Adhortacja apostolska, Reconciliatio et poenitentia (2 grudnia 1984), https://opoka. org.pl/biblioteka/W/WP/jan_pawel_ii/adhortacje/reconciliatio.html [dostęp: 31.07.2018].

Kampowski S., Granados J., Pérez-Soba J. (2016), Amoris laetitia. Accopmagnare, discernere, integrare, Rzym.

Katechizm Kościoła katolickiego (1994), Poznań.

Kodeks Prawa Kanonicznego. Komentarz, edycja polska na podstawie wydania hiszpańskiego, red. P. Majer, Wolters Kluwer, Kraków 2011.

Kongregacja Nauki Wiary (1994), List do biskupów Kościoła katolickiego na temat przyjmowania Komunii św. przez wiernych rozwiedzionych żyjacych w nowych związkach (14 września 1994), http://www.vatican.va/roman_curia/congregations/cfaith/documents/rc_con_cfaith_doc_ 14091994_rec-holy-comm-by-divorced_pl.html [dostęp: 31.07.2018].

Kupczak J., Jakklewicz T. (2017), Przeciętność to nie ideat. O debacie wokót adhortacji „Amoris laetitia” $i$ wierności nauczaniu Jana Pawła II o rodzinie mówi Jan Pawet II, „Gość Niedzielny” 5 marca, $\mathrm{nr} 9$.

Melina L. (1996), Moral. Entre la crisis y la renovación, Barcelona.

Międzynarodowa Komisja Teologiczna (2010), W poszukiwaniu etyki uniwersalnej: nowe spojrzenie na prawo naturalne (27 marca 2009), Kraków.

Papieska Rada ds. Rodziny (1997), Vademecum dla spowiedników. O niektórych zagadnieniach moralnych dotyczących życia matżeńskiego (12 lutego 1997), http://www.spowiedz.pl/vademecum.htm [dostęp: 31.07.2018].

Ratzinger J. (1985), Le fonti della teologia morale, Cris Documenti, Rzym.

Ratzinger J. (1981), Podsumowanie dyskusji nad „Dokumentem podstawowym”, „Chrześcijanin w Świecie" nr 98, s. 16-20.

Styczeń T. (1999), Prudencia y fatiga del amor conyugal, [w:] Consejo Pontificio para la Familia, Moral conyugal y sacramento de la penitentia, Reflexiones sobre el Vademecum para confesores, Madrid, s. 148-150. 
Szostek A. (1990), Natura, rozum, wolność. Filozoficzna analiza koncepcji twórczego rozumu we współczesnej teologii moralnej, Rzym.

Świerczek A. (2013), Wolne związi w świetle nauczania Kościoła o matżeństwie, Kraków.

Tomasz z Akwinu (1975-1986), Suma teologiczna, thum. P. Bełch, London

Wicher W. (1969), Podstawy teologii moralnej, Poznań-Warszawa-Lublin.

You A. (1991), La loi de gradualité: une nouveauté en morale?, Paris.

KRZYSZTOF GRYZ - ks. dr hab., kapłan archidiecezji krakowskiej, ur. w 1961 r. w Chrzanowie. W latach 1980-1986 studia na Papieskiej Akademii Teologicznej w Krakowie. Studia specjalistyczne z teologii moralnej na Uniwersytecie Nawarry w Pampelunie (1990-1994). Obecnie pracownik naukowy Uniwersytetu Papieskiego Jana Pawła II w Krakowie, kierownik Katedry Teologii Moralnej Ogólnej. Członek Stowarzyszenia Teologów Moralistów. 